\title{
Tumour necrosis factor-like weak inducer of apoptosis (TWEAK) in kidney disease: a biomarker or therapeutic target?
}

\author{
Podobny do czynnika martwicy nowotworów induktor apoptozy (TWEAK) w chorobach nerek - \\ biomarker czy cel terapeutyczny?
}

\author{
1 Department of Clinical Paediatrics, University of Warmia and Mazury, Regional Specialised Children's Hospital in Olsztyn, Olsztyn, Poland \\ ${ }^{2}$ Department of Emergency Medicine, Medical University of Bialystok, Białystok, Poland \\ ${ }^{3}$ Department of Paediatrics and Nephrology, Medical University of Bialystok, Białystok, Poland \\ Correspondence: Katarzyna Taranta-Janusz, MD, Department of Paediatrics and Nephrology, Medical University of Bialystok, Waszyngtona 17, 15-274 Białystok, Poland, \\ tel.: +48 857450651 , fax:+48 85742 1838, e-mail: katarzyna.taranta@wp.pl
}

\begin{abstract}
Kidney disease is a significant public health problem that is increasing worldwide. Tumour necrosis factor superfamily molecules have recently been shown to be actively involved in renal pathophysiology. According to current reports, one of these molecules has significant clinical implications: TWEAK, a tumour necrosis factor-like weak inducer of apoptosis. TWEAK is a cytokine with important functions. By binding to induced fibroblast growth factor 14 (Fn14), its only receptor, TWEAK activates various biological processes, including cell growth, migration or death, angiogenesis and production of proinflammatory cytokines. TWEAK and Fn14 expression is relatively low in healthy tissues. Experimental studies have confirmed the important role of TWEAK/Fn14 pathway activation in physiological tissue repair and regeneration, while its excessive activation leads to acute and/or chronic damage. TWEAK production takes place in various inflammatory diseases of the kidneys with the participation of immune cells. In the case of inflammatory diseases characterised by increased chemokine production, TWEAK presents with apoptotic effects. In non-immune diseases, TWEAK stimulates renal tubular proliferation. The dualism of the TWEAK effect is multifactorial. TWEAK was proliferative in healthy kidneys and in a compensatory overgrowth model after nephrectomy in which inflammatory cytokine expression was low. Data obtained from experimental and clinical studies are useful for developing future diagnostic and therapeutic strategies focused on the role of TWEAK in kidney damage.
\end{abstract}

Keywords: cytokines, kidney diseases, TWEAK, fibrosis

Streszczenie Choroby nerek to istotny problem zdrowia publicznego, którego wzrost występowania obserwuje się na całym świecie. Ostatnio wykazano, że cząsteczki nadrodziny czynnika martwicy nowotworów (TNF) są aktywnie zaangażowane w patofizjologię nerek. Według aktualnych doniesień jedną z tych cząsteczek jest mający istotne implikacje kliniczne TWEAK podobny do czynnika martwicy nowotworów induktor apoptozy. TWEAK to cytokina pełniąca ważne funkcje. Poprzez wiązanie $\mathrm{z}$ indukowanym czynnikiem wzrostu fibroblastów 14 (Fn14) - jego jedynym receptorem - TWEAK aktywuje różne procesy biologiczne, w tym wzrost, migrację lub śmierć komórek, angiogenezę i wytwarzanie cytokin prozapalnych. W zdrowych tkankach ekspresja TWEAK i Fn14 jest stosunkowo niska. Badania eksperymentalne potwierdziły istotną rolę aktywacji szlaku TWEAK/Fn14 w fizjologicznej naprawie i regeneracji tkanek, podczas gdy jego nadmierna aktywacja prowadzi do ich ostrego i/lub przewlekłego uszkodzenia. Produkcja TWEAK ma miejsce w różnych stanach zapalnych nerki, przy udziale komórek odpornościowych. W przypadku chorób zapalnych charakteryzujących się zwiększoną lokalną ekspresją TWEAK i cytokin zapalnych TWEAK wykazuje działanie apoptotyczne. W chorobach o podłożu nieimmunologicznym TWEAK pobudza zaś proliferację cewek nerkowych. Dualizm efektu działania TWEAK jest wieloczynnikowy. W zdrowych nerkach i eksperymentalnym przeroście kompensacyjnym po nefrektomii, w którym ekspresja cytokin zapalnych jest niska, TWEAK wykazywał działanie proliferacyjne. Dane uzyskane z badań eksperymentalnych i klinicznych mogą być przydatne do opracowania przyszłych strategii diagnostycznych i terapeutycznych ukierunkowanych na rolę TWEAK w uszkodzeniu nerek.

Słowa kluczowe: cytokiny, choroby nerek, TWEAK, włóknienie 


\section{INTRODUCTION}

$\mathrm{K}$ idney disease is a significant public health problem that is increasing worldwide. It is associated with population ageing and an increasing prevalence of lifestyle diseases such as diabetes, hypertension, obesity and concomitant immune disorders. Chronic kidney disease (CKD) is an independent risk factor for cardiovascular disease, which additionally increases morbidity and mortality among individuals with CKD. Tumour necrosis factor (TNF) superfamily molecules have recently been shown to play an important role in kidney disease pathogenesis. One of these molecules is tumour necrosis factor-like weak inducer of apoptosis (TWEAK), which has been investigated and discussed in detail in recent years. TWEAK is able to activate key pathways associated with the development and progression of kidney disease by affecting the processes of cell proliferation, differentiation, apoptosis, necrosis, inflammation, angiogenesis and fibrosis. Tab. 1 summarises the influence of TWEAK on different renal cells in vitro by affecting the processes of cell proliferation, inflammation, fibrosis and death ${ }^{(1-15)}$.

TWEAK was first described in 1997 by Chicheportiche et al., who found that one of the TNF family particles is able to induce apoptosis ${ }^{(16)}$. TWEAK is a multifunctional cytokine which mediates many processes with a potential pathophysiological significance dependent on the microenvironment, type and activation status of the cell. By binding to fibroblast growth factor-inducible 14 (Fn14), which is the only TWEAK receptor, TWEAK stimulates various biological processes such as cell proliferation, migration, apoptosis and angiogenic activity, and can lead to inflammatory cytokine overexpression and impaired cellular differentiation pathways ${ }^{(17)}$. On a molecular level, TWEAK/Fn14 signalling initiates the binding of TWEAK with the extracellular domain of its receptor; subsequently, the signal is transmitted by factors associated with the
TNF receptor, which mediate the activation of canonical and non-canonical nuclear factor kappa B (NF- $\kappa \mathrm{B})$ pathways $^{(18-21)}$. Through the activation of NF- $\kappa B$, TWEAK stimulates mesangial cells, podocytes and tubular cells to express many inflammatory mediators, including cytokines/ chemokines (regulated on activation, normal $\mathrm{T}$ cell expressed and secreted, RANTES; monocyte chemoattractant protein-1, MCP-1) $)^{(22)}$.

Opposite effects of TWEAK activity were also discovered: on the one hand, it leads to the processes of repair and regeneration; on the other hand, excessive, chronic activation of TWEAK causes tissue damage and neoplasia ${ }^{(23-26)}$.

Under normal conditions, TWEAK and Fn14 expression is low; however, it increases with tissue damage ${ }^{(27,28)}$. Numerous experimental studies and research papers demonstrated the lack of Fn14 expression in a healthy kidney. However, a significant increase in the expression of Fn 14 with TWEAK was observed in various forms of acute and chronic kidney injury, proteinuric and nonproteinuric kidney diseases, and in immune ${ }^{(29)}$, inflammatory and neoplastic diseases ${ }^{(27,28)}$.

An increasing body of evidence confirms that the activation of the TWEAK/Fn14 pathway plays a key role in the pathophysiology of many kidney diseases. Clinical symptoms, laboratory tests and invasive procedures (kidney biopsy, cystoscopy) do not meet the requirements of modern diagnostic investigation. Recent publications have shed a new light on the role of TWEAK in kidney inflammation and fibrosis and in neoplastic diseases of the urinary tract. For this reason, a search is under way for new biomarkers for determining and monitoring the course of disease.

This article summarises the findings made to date, with a focus on predictive and therapeutic implications of the assessment of TWEAK/Fn14 pathway expression and TWEAK concentration in selected kidney diseases.

\begin{tabular}{|c|c|c|c|}
\hline TWEAK - in vitro effect & Target renal cell & Mechanism of action and cofactors & References \\
\hline Fibrosis & $\begin{array}{l}\text { Mesangium } \\
\text { Tubules }\end{array}$ & $\begin{array}{l}\uparrow \text { TGF- } \beta 1 \text {, fibronectin } \\
\text { NF-KB-mediated epithelial-mesenchymal } \\
\text { transition }\end{array}$ & $\begin{array}{l}(2) \\
(3)\end{array}$ \\
\hline Inflammation & $\begin{array}{l}\text { Tubules } \\
\text { Podocytes } \\
\text { Mesangium }\end{array}$ & $\begin{array}{l}\text { † MCP-1, RANTES, CXCL16 (NF-kB pathway) } \\
\uparrow \text { CCL21 (non-canonical NF-kB pathway) } \\
\uparrow \text { MCP-1, RANTES, CCL19 (NF-kB pathway) } \\
\uparrow \text { CCL21 (non-canonical NF-kB pathway) } \\
\uparrow \text { MCP-1, IL-6, IL-8 (NF-kB pathway) }\end{array}$ & $\begin{array}{l}(4-9) \\
(10,11) \\
(12)\end{array}$ \\
\hline Proliferation & \begin{tabular}{|l} 
Tubules \\
Mesangium \\
Fibroblasts \\
\end{tabular} & $\begin{array}{l}\text { Increase in cell numbers (NF-kB pathway) } \\
\text { Cell proliferation } \\
\text { Increased cell cycle activity } \\
\text { Increased mitotic index } \\
\end{array}$ & $\begin{array}{l}(13) \\
(12) \\
(4) \\
\end{array}$ \\
\hline Cell death & Tubules & Apoptosis induction & $(14,15)$ \\
\hline
\end{tabular}




\section{TWEAK IN EXPERIMENTAL RESEARCH}

The first study on the impact of TWEAK and its receptor on renal tubular cells was conducted on a murine model. In the mice, acute kidney injury (AKI) was induced by administering folic acid. It was found that in the presence of proinflammatory cytokines (TNF- $\alpha$, interferon $\gamma-$ IFN- $\gamma$ ) TWEAK activation leads to renal tubular damage. Cell death is associated with the activation of caspase- 8 and the mitochondrial apoptosis pathway. Caspase inhibitors prevent apoptosis; however, they promote oxidative stress and tubular tissue necrosis ${ }^{(22,30)}$

In a non-inflammatory microenvironment, for example in the presence of growth factors, TWEAK promotes NF- $\kappa B$ and mitogen-activated protein kinases (MAPK), which leads to the proliferation of renal tubular epithelium.

In an AKI model associated with tubular damage, proliferation and inflammation, TWEAK deficiency or the administration of anti-TWEAK antibodies limited kidney apoptosis and inflammation ${ }^{(6,22)}$, resulting in functional improvement $^{(13,31)}$. Similar results were obtained for an ischaemia-reperfusion AKI model in which blocking the Fn14 receptor reduced kidney apoptosis and fibrosis ${ }^{(32)}$. In these observations, the administration of anti-TWEAK antibodies significantly reduced the inflammatory process in the kidney $^{(33)}$. In a chronic graft-versus-host disease (GvHD) nephritis model, anti-TWEAK antibodies significantly reduced the expression of proinflammatory cytokines, macrophage infiltration and proteinuria ${ }^{(34)}$. In addition, TWEAK deficiency significantly reduced kidney apoptosis, inflammation and fibrosis in a model with a ligated ureter ${ }^{(4)}$.

In experimental animals devoid of the Fn14 receptor, macrophage and $\mathrm{T}$ cell infiltration in the kidney was observed to be reduced. Thus, it may be concluded that the activation of TWEAK/Fn14 increases inflammatory reactions by promoting cytokine production and inflammatory cell infiltration $^{(6)}$.

The proliferative effect of TWEAK was also assessed for unilateral nephrectomy. Tubular cell proliferation and kidney hypertrophy were found despite the lack of signs of kidney injury. It was demonstrated that in the remaining kidney, tubular Fn14 expression increases within several days, without changes in the numbers of proinflammatory cytokines, which sensitises tubular cells to TWEAK and increases cell proliferation $^{(13)}$. TWEAK knock-out mice displayed an impaired response to unilateral nephrectomy, which suggests that the TWEAK/Fn14 pathway also mediates compensatory hypertrophy in unilateral nephrectomy.

\section{TWEAK IN LUPUS NEPHRITIS}

Lupus nephritis (LN) is one of the more common clinical manifestations of systemic lupus erythematosus. The highly diverse course of LN requires quick and thorough diagnostic investigation. The markers that have been used to date to diagnose LN, such as: proteinuria, erythrocyturia, urine albumin/creatinine index, creatinine clearance, anti-dsDNA antibodies and complement component levels are highly insufficient ${ }^{(35)}$. Kidney biopsy, which remains the diagnostic gold standard, is an invasive method that is not always possible to perform and which is of little use for treatment monitoring. Therefore, there is an urgent need to determine reliable biomarkers assessed qualitatively and quantitatively in blood and/or urine.

TWEAK is produced in various inflammatory kidney conditions, with a significant contribution from immune cells such as macrophages. As mentioned previously, under normal conditions the activation and production of TWEAK and Fn14 in the kidney are relatively low. However, in patients with lupus, both glomeruli and tubules display a high TWEAK and Fn14 expression ${ }^{(36)}$. In an experimental murine lupus model, TWEAK expression was elevated already at an early stage of the disease ${ }^{(37)}$. In addition, animals with experimentally induced LN had significantly higher TWEAK/Fn14 levels in the glomeruli compared to the group with no renal involvement ${ }^{(6,38)}$.

TWEAK/Fn 14 activation in the kidneys promotes the production of many proinflammatory cytokines that initiate disease progression in systemic lupus. As a result of TWEAK/Fn14 activation, proinflammatory cytokines, including RANTES, MCP-1 and IFN- $\gamma$-induced protein 10 , are expressed by human renal cells or renal cells of mice with $\mathrm{LN}^{(38)}$. Due to TWEAK, in renal tubular cells, additional inflammatory cytokines are expressed, such as chemokine ligand 19 (CCL19), 21 (CCL21) and 16 (CXCL16) (Fig. 1$)^{(39,40)}$. Inflammatory cytokine overexpression exacerbates local inflammation in LN. RANTES and MCP-1 lead to the infiltration of the kidneys by macrophages, monocytes and activated T cells, which are instrumental in the pathogenesis of renal impairment in $\mathrm{LN}^{(41)}$. The RANTES cytokine significantly accelerated the progression of LN in mice, while experimentally induced lack of MCP-1 significantly reduced $\mathrm{T}$ cell and macrophage infiltration, thus limiting glomerular sclerosis and crescent formation ${ }^{(42)}$.

It was demonstrated that RANTES plays a role in the development of glomerulonephritis. Studies in which urine TWEAK concentration was assessed in patients with LN demonstrated that it correlates with LN activity and can be useful in making therapeutic decisions ${ }^{(12,42,43)}$. Schwartz et al. ${ }^{(43)}$ also confirmed that urine TWEAK concentration was significantly higher in patients with LN and correlated with SLEDAI score (Systemic Lupus Erythematosus Disease Activity Index).

With regard to renal proinflammatory effects of TWEAK, based on numerous observations of a murine lupus model and preliminary clinical studies in which TWEAK and Fn14 expression in the kidneys increased with disease progression $^{(44)}$, a hypothesis was put forward that TWEAK/Fn14 interactions play a fundamental role in $\mathrm{LN}$ pathogenesis. Furthermore, an ability to modify the cellular pathway mentioned above can constitute a new therapeutic target. In order to clarify this matter, intravenous administration 


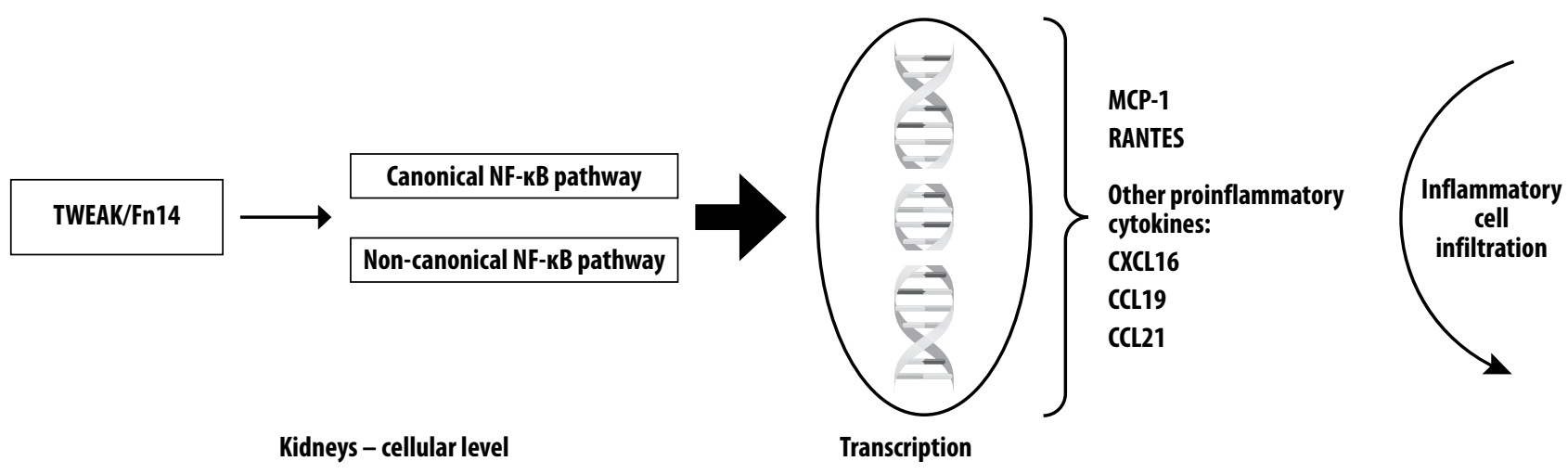

CCL19-chemokine ligand 19; CCL21 - chemokine ligand 21; CXCL16 - chemokine ligand 16, Fn14-fibroblast growth factor-inducible 14; MCP-1 - monocyte chemoattractant protein-1; NF-KB - nuclear factor kappa-light-chain-enhancer of activated B cells; RANTES - regulated on activation, normal T cell expressed and secreted; TWEAK - tumour necrosis factor-related weak inducer of apoptosis

Fig. 1. TWEAK/Fn14 pathway in activation and modulation of proinflammatory cytokine production

of anti-TWEAK antibodies was started in systemic inflammatory diseases, which caused serum TWEAK concentration to drop down to indeterminate values and the levels of circulating inflammatory markers to be significantly reduced in patients with rheumatoid arthritis ${ }^{(45)}$. However, in the ATLAS study (Anti-Tweak in Lupus Nephritis Patients), which assessed the efficacy, safety and tolerability of anti-TWEAK antibodies as an add-on therapy in patients with advanced LN in whom standard of care did not produce remission ${ }^{(25)}$, anti-TWEAK antibodies were not found to be sufficiently effective in comparison to routinely used steroids and mycophenolate mofetil.

Apart from the potential of anti-TWEAK therapy in inflammatory diseases with renal involvement, there is abundant evidence suggesting that TWEAK can also serve as a biomarker of renal impairment.

While serum TWEAK levels did not make it possible to identify patients with $\mathrm{LN}^{(46,47)}$, TWEAK excretion with urine was indeed significantly higher in them. This made it possible to differentiate these patients from those with other autoimmune diseases and from healthy controls ${ }^{(46)}$. As a result, urine TWEAK concentration started to be investigated as a possible non-invasive tool for monitoring the disease ${ }^{(48,49)}$.

\section{TWEAK AND CKD}

Chronic kidney disease is associated with accelerated ageing and premature death ${ }^{(50)}$. It is also an independent risk factor for the development of cardiovascular diseases, which, in turn, impair kidney function even further ${ }^{(51)}$. For this reason, early diagnosis and identification of factors that increase susceptibility to kidney damage are very important.

As numerous studies suggest, the pathomechanism of renal impairment in CKD is a multifactorial process in which inflammation may play an important role; this is supported by elevated inflammatory marker levels in patients with
Chronic kidney disease is considered to be a state of Klotho protein deficiency which may contribute to accelerated ageing ${ }^{(50)}$. Klotho protein has profibrotic, anti-ageing and anti-inflammatory properties ${ }^{(54-57)}$, while TWEAK is a key factor in reducing Klotho expression through the canonical activation of the NF- $\mathrm{kB}$ pathway ${ }^{(55)}$. It was proven that, on the one hand, the TWEAK/Fn14 system activates proinflammatory pathways via NF- $\mathrm{KB}$, and, on the other hand, it attenuates anti-inflammatory and anti-ageing pathways; as such, TWEAK/Fn14 is a potential factor affecting the ageing process associated with inflammation ${ }^{(58)}$.

Research on CKD patients demonstrated that TWEAK may serve as a biomarker of renal impairment and concomitant organ complications ${ }^{(59)}$. Sasaki et al. demonstrated the existence of a relationship between urine TWEAK level and clinical symptoms suggesting that the TWEAK/ Fn14 system affects crescent formation and proteinuria in patients with IgA nephropathy ${ }^{(60)}$. Studies on haemodialysis patients demonstrated significantly lower serum TWEAK levels in relation to the control group ${ }^{(61,62)}$. However, an increase in serum TWEAK levels in certain haemodialysis patients was associated with elevated cardiovascular risk and higher mortality ${ }^{(61)}$. Based on this, Carrero et al. found that TWEAK may also be a marker of high mortality in haemodialysis patients ${ }^{(61)}$. In renal transplant patients, an increase in TWEAK concentration was observed as well ${ }^{(62)}$. Based on research to date, TWEAK can be considered a potential biomarker of the development and progression of CKD and diabetic nephropathy, and a biomarker of cardiovascular risk in kidney diseases ${ }^{(28,63,64)}$.

\section{TWEAK AND KIDNEY FIBROSIS}

There is also evidence for a profibrotic role of TWEAK and Fn14 in the kidney. Experimental research demonstrated that TWEAK can contribute to kidney fibrosis by modifying and stimulating such processes as fibroblast 
proliferation, activation of tubular cells to synthesise proinflammatory mediators or reduction of antifibrotic molecule levels ${ }^{(32)}$.

It has been proven that TWEAK activates the proinflammatory response via NF- $\kappa \mathrm{B}$ in fibroblasts. By affecting renal fibroblasts, TWEAK induces the process of kidney fibrosis. This was confirmed in an experimental study on mice with unilateral ureteral obstruction. The mice which were not able to produce TWEAK had a decreased renal fibrosis ${ }^{(4)}$. In addition, a lower degree of tubulointerstitial tissue damage was observed in the kidney with obstructed urine outflow and no TWEAK. These observations are important due to the fact that eliminating TWEAK reduced the process of kidney fibrosis in a chronic, non-immune model of kidney injury. Based on in vivo study results, it is suggested that TWEAK/Fn14 blockade can protect against kidney injury/disease.

Experimental and clinical studies have produced evidence for the indisputably important role of TWEAK in kidney injury prevention therapy. Promising results of clinical studies on anti-TWEAK antibodies provide a chance for further exploration of other kidney diseases in which TWEAK might constitute a therapeutic target. The potential role of TWEAK in kidney regeneration also seems important.

In conclusion, despite the lack of advanced clinical trials, there is a body of preclinical evidence linking TWEAK with kidney injury. Knowledge building and further studies using new techniques to assess the role of TWEAK as an important factor in the pathomechanism, course and method of treatment of kidney diseases with various aetiology will be of key importance.

\section{Conflict of interest}

The authors do not report any financial or personal affiliations to persons or organisations that could adversely affect the content of or claim to have rights to this publication.

\section{References}

1. Sanz AB, Sanchez-Niño MD, Ortiz A: TWEAK, a multifunctional cytokine in kidney injury. Kidney Int 2011; 80: 708-718.

2. Martín P, Mora I, Cortes MA et al.: Relevant role of PKG in the progression of fibrosis induced by TNF-like weak inducer of apoptosis. Am J Physiol Renal Physiol 2014; 307: F75-F85.

3. Berzal S, González-Guerrero C, Rayego-Mateos S et al.: TNF-related weak inducer of apoptosis (TWEAK) regulates junctional proteins in tubular epithelial cells via canonical NF- $\mathrm{\kappa B}$ pathway and ERK activation. J Cell Physiol 2015; 230: 1580-1593.

4. Ucero ÁC, Benito-Martin A, Fuentes-Calvo I et al.: TNF-related weak inducer of apoptosis (TWEAK) promotes kidney fibrosis and Ras-dependent proliferation of cultured renal fibroblast. Biochim Biophys Acta 2013; 1832: 1744-1755.

5. Ucero ÁC, Berzal S, Ocaña-Salceda $C$ et al.: A polymeric nanomedicine diminishes inflammatory events in renal tubular cells. PLoS One 2013; 8: e51992.

6. Izquierdo MC, Sanz AB, Mezzano $S$ et al.: TWEAK (tumor necrosis factor-like weak inducer of apoptosis) activates CXCL16 expression during renal tubulointerstitial inflammation. Kidney Int 2012; 81: 1098-1107.

7. Valiño-Rivas L, Cuarental L, Grana O et al.: TWEAK increases CD74 expression and sensitizes to DDT proinflammatory actions in tubular cells. PLoS One 2018; 13: e0199391.

8. Ortiz A, Husi H, Gonzalez-Lafuente L et al.: Mitogen-activated protein kinase 14 promotes AKI. J Am Soc Nephrol 2017; 28: 823-836.

9. Poveda J, Sanz AB, Carrasco $S$ et al.: Bcl3: a regulator of NF- $\kappa B$ inducible by TWEAK in acute kidney injury with anti-inflammatory and antiapoptotic properties in tubular cells. Exp Mol Med 2017; 49: e352.

10. Sanchez-Niño MD, Poveda J, Sanz AB et al.: Fn14 in podocytes and proteinuric kidney disease. Biochim Biophys Acta 2013; 1832: 2232-2243.

11. Valiño-Rivas L, Gonzalez-Lafuente L, Sanz AB et al.: Noncanonical NF- $\mathrm{kB}$ activation promotes chemokine expression in podocytes. Sci Rep 2016; 6: 28857.

12. Sun F, Teng J, Yu P et al.: Involvement of TWEAK and the NF- $\kappa B$ signaling pathway in lupus nephritis. Exp Ther Med 2018: 15: 2611-2619.

13. Sanz AB, Sanchez-Niño MD, Izquierdo MC et al.: TWEAK induces proliferation in renal tubular epithelium: a role in uninephrectomy induced renal hyperplasia. J Cell Mol Med 2009; 13: 3329-3342.

14. Martin-Sanchez D, Fontecha-Barriuso M, Carrasco S et al.: TWEAK and RIPK1 mediate a second wave of cell death during AKI. PNAS 2018; 115: 4182-4187.

15. Poveda J, Sanchez-Niño MD, Glorieux G et al.: $p$-Cresyl sulphate has pro-inflammatory and cytotoxic actions on human proximal tubular epithelial cells. Nephrol Dial Transplant 2014; 29: 56-64.

16. Chicheportiche Y, Bourdon PR, Xu H et al.: TWEAK, a new secreted ligand in the tumor necrosis factor family that weakly induces apoptosis. J Biol Chem 1997; 272: 32401-32410.

17. Trebing J, Arana JA, Salzmann S et al.: Analyzing the signaling capabilities of soluble and membrane TWEAK. Methods Mol Biol 2014; 1155: 31-45.

18. Hénaut L, Sanz AB, Martin-Sanchez D et al.: TWEAK favors phosphate-induced calcification of vascular smooth muscle cells through canonical and non-canonical activation of NF-kB. Cell Death Dis 2016; 7: e2305.

19. Burkly LC: Regulation of tissue responses: the TWEAK/Fn14 pathway and other TNF/TNFR superfamily members that activate non-canonical NF-kB signaling. Front Immunol 2015; 6: 92.

20. Sanz AB, Sanchez-Niño MD, Izquierdo MC et al.: TWEAK activates the non-canonical NF- $\mathrm{\kappa B}$ pathway in murine renal tubular cells: modulation of CCL21. PLoS One 2010; 5: e8955.

21. Saitoh T, Nakayama M, Nakano $H$ et al.: TWEAK induces NF- $\kappa$ B2 p100 processing and long lasting NF- $\mathrm{BB}$ activation. J Biol Chem 2003; 278: 36005-36012.

22. Sanz AB, Justo P, Sanchez-Niño MD et al.: The cytokine TWEAK modulates renal tubulointerstitial inflammation. J Am Soc Nephrol 2008; 19: 695-703.

23. Zheng TS, Burkly LC: No end in site: TWEAK/Fn14 activation and autoimmunity associated- end-organ pathologies. J Leukoc Biol 2008; 84: 338-347.

24. Winkles JA. The TWEAK-Fn14 cytokine-receptor axis: discovery, biology and therapeutic targeting. Nat Rev Drug Discov 2008; 7: 411-425.

25. Michaelson JS, Wisniacki N, Burkly LC et al.: Role of TWEAK in lupus nephritis: a bench-to-bedside review. J Autoimmun 2012; 39: 130-142.

26. Liu ZC, Zhou QL: Tumor necrosis factor-like weak inducer of apoptosis and its potential roles in lupus nephritis. Inflamm Res 2012; 61: 277-284.

27. Burkly LC, Michaelson JS, Hahm $\mathrm{K}$ et al.: TWEAKing tissue remodeling by a multifunctional cytokine: role of TWEAK/Fn14 pathway in health and disease. Cytokine 2007; 40: 1-16.

28. Sanz AB, Izquierdo MC, Sanchez-Niño MD et al.: TWEAK and the progression of renal disease: clinical translation. Nephrol Dial Transplant 2014; 29 Suppl 1: i54-i62. 
29. Sanz AB, Ruiz-Andres O, Sanchez-Niño MD et al.: Out of the TWEAKlight: elucidating the role of Fn 14 and TWEAK in acute kidney injury. Semin Nephrol 2016; 36: 189-198.

30. Justo P, Sanz AB, Sanchez-Niño MD et al.: Cytokine cooperation in renal tubular cell injury: the role of TWEAK. Kidney Int 2006; 70: 1750-1758.

31. Sanz AB, Santamaria B, Ruiz-Ortega M et al.: Mechanisms of renal apoptosis in health and disease. J Am Soc Nephrol 2008; 19: 1634-1642.

32. Hotta K, Sho M, Yamato I et al.: Direct targeting of fibroblast growth factor-inducible 14 protein protects against renal ischemia reperfusion injury. Kidney Int 2011; 79: 179-188.

33. Muñoz-Garcia B, Moreno JA, López-Franco O et al.: Tumor necrosis factor-like weak inducer of apoptosis (TWEAK) enhances vascular and renal damage induced by hyperlipidemic diet in ApoEknockout mice. Arterioscler Thromb Vasc Biol 2009; 29: 2061-2068.

34. Zhao Z, Burkly LC, Campbell S et al.: TWEAK/Fn14 interactions are instrumental in the pathogenesis of nephritis in the chronic graft-versus-host model of systemic lupus erythematosus. J Immunol 2007; 179: 7949-7958.

35. Rovin $\mathrm{BH}$, Zhang X: Biomarkers for lupus nephritis: the quest continues. Clin J Am Soc Nephrol 2009; 4: 1858-1865.

36. Molano A, Lakhani P, Aran A et al.: TWEAK stimulation of kidney resident cells in the pathogenesis of graft versus host induced lupus nephritis. Immunol Lett 2009; 125: 119-128.

37. Lee SB, Kalluri R: Mechanistic connection between inflammation and fibrosis. Kidney Int 2010; 78 Suppl 119: S22-S26.

38. Burkly LC, Michaelson JS, Zheng TS: TWEAK/Fn14 pathway: an immunological switch for shaping tissue responses. Immunol Rev 2011; 244: 99-114.

39. Rodrigues-Díez R, Rodrigues-Díez RR, Rayego-Mateos S et al.: The C-terminal module IV of connective tissue growth factor is a novel immune modulator of the Th17 response. Lab Invest 2013; 93: 812-824.

40. Jain M, Jakubowski A, Cui L et al.: A novel role for tumor necrosis factor-like weak inducer of apoptosis (TWEAK) in the development of cardiac dysfunction and failure. Circulation 2009; 119: 2058-2068.

41. Chen HN, Wang DJ, Ren MY et al.: TWEAK/Fn14 promotes the proliferation and collagen synthesis of rat cardiac fibroblasts via the NF- $\mathrm{BB}$ pathway. Mol Biol Rep 2012; 39: 8231-8241.

42. Dhaun N, Kluth DC: TWEAK: a novel biomarker for lupus nephritis? Arthritis Res Ther 2009; 11: 133.

43. Schwartz N, Su L, Burkly LC et al.: Urinary TWEAK and the activity of lupus nephritis. J Autoimmun 2006; 27: 242-250.

44. Xia Y, Campbell SR, Broder A et al.: Inhibition of the TWEAK/ Fn14 pathway attenuates renal disease in nephrotoxic serum nephritis. Clin Immunol 2012; 145: 108-121.

45. Galluppi GR, Wisniacki N, Stebbins C: Population pharmacokinetic and pharmacodynamic analysis of BIIB023, an anti-TNFlike weak inducer of apoptosis (anti-TWEAK) monoclonal antibody. Br J Clin Pharmacol 2016; 82: 118-128.

46. Schwartz N, Rubinstein T, Burkly LC et al.: Urinary TWEAK as a biomarker of lupus nephritis: a multicenter cohort study. Arthritis Res Ther 2009; 11: R143.
47. Wang C, Chen LL, Pan HF et al.: Expression of human tumor necrosis factor-like weak inducer of apoptosis in patients with systemic lupus erythematosus. Clin Rheumatol 2012; 31: 335-339.

48. El-Shehaby A, Darweesh H, El-Khatib M et al.: Correlations of urinary biomarkers, TNF-like weak inducer of apoptosis (TWEAK), osteoprotegerin (OPG), monocyte chemoattractant protein-1 (MCP-1), and IL-8 with lupus nephritis. J Clin Immunol 2011; 31: 848-856.

49. Reyes-Thomas J, Blanco I, Putterman C: Urinary biomarkers in lupus nephritis. Clin Rev Allergy Immunol 2011; 40: 138-150.

50. Izquierdo MC, Perez-Gomez MV, Sanchez-Niño MD et al.: Klotho, phosphate and inflammation/ageing in chronic kidney disease. Nephrol Dial Transplant 2012; 27 Suppl 4: iv6-i10.

51. Levin A, Tonelli M, Bonventre J et al.; ISN Global Kidney Health Summit participants: Global kidney health 2017 and beyond: a roadmap for closing gaps in care, research, and policy. Lancet 2017; 390: 1888-1917.

52. Elewa U, Sanchez-Niño MD, Martin-Cleary C et al.: Cardiovascular risk biomarkers in CKD: the inflammation link and the road less traveled. Int Urol Nephrol 2012; 44: 1731-1744.

53. Ortiz A, Massy ZA, Fliser D et al.: Clinical usefulness of novel prognostic biomarkers in patients on hemodialysis. Nat Rev Nephrol 2011; 8: 141-150.

54. Sanchez-Niño MD, Sanz AB, Ortiz A: Klotho to treat kidney fibrosis. J Am Soc Nephrol 2013; 24: 687-689.

55. Moreno JA, Izquierdo MC, Sanchez-Niño MD et al.: The inflammatory cytokines TWEAK and TNFa reduce renal Klotho expression through NFkB. J Am Soc Nephrol 2011; 22: 1315-1325.

56. Kuro-o M, Matsumura $\mathrm{Y}$, Aizawa $\mathrm{H}$ et al.: Mutation of the mouse Klotho gene leads to a syndrome resembling ageing. Nature 1997; 390: 45-51.

57. Kurosu H, Yamamoto M, Clark JD et al.: Suppression of aging in mice by the hormone Klotho. Science 2005; 309: 1829-1833.

58. Izquierdo MC, Sanz AB, Sanchez-Niño MD et al.: Acute kidney injury transcriptomics unveils a relationship between inflammation and ageing. Nefrologia 2012; 32: 715-723.

59. Yilmaz MI, Carrero JJ, Ortiz A et al.: Soluble TWEAK plasma levels as a novel biomarker of endothelial function in patients with chronic kidney disease. Clin J Am Soc Nephrol 2009; 4: 1716-1723.

60. Sasaki Y, Shimizu Y, Suzuki Y et al.: TWEAK/Fn14 system and crescent formation in IgA nephropathy. BMC Nephrology 2015; 16: 27.

61. Carrero JJ, Ortiz A, Qureshi AR et al.: Additive effects of soluble TWEAK and inflammation on mortality in hemodialysis patients. Clin J Am Soc Nephrol 2009; 4: 110-118.

62. Eskandari Naji H, Ghorbanihaghjo A, Argani H et al.: Serum sTWEAK and FGF-23 levels in hemodialysis and renal transplant patients. Int J Organ Transplantation Med 2017; 8: 110-116.

63. Sharif MN, Campanholle G, Nagiec EE et al.: Soluble Fn14 is detected and elevated in mouse and human kidney disease. PLoS One 2016; 11: e0155368.

64. Bernardi S, Voltan R, Rimondi E et al.: TRAIL, OPG, and TWEAK in kidney disease: biomarkers or therapeutic targets? Clin Sci (Lond) 2019; 133: 1145-1166. 